\title{
Micro encapsulation of Bovine Spermatozoa: Cryopreservation of Microencapsulation Sperm using Glycerol
}

\author{
Kusumaningrum DA ${ }^{1,2}$, Purwantara $\mathrm{B}^{2}$, Yusuf $\mathrm{TL}^{2}$, Situmorang $\mathrm{P}^{1}$ \\ ${ }^{1}$ Indonesian Research Institute for Animal Production, PO Box 221, Bogor 16002 \\ ${ }^{2}$ Division of Veterinary Reproduction, Obstetrics and Gynecology, Faculty of Veterinary Medicine, Bogor Agricultural University \\ E-mail:da_kusumaningrum@yahoo.com
}

(received 10-11-2015; revised 26-11-2015; accepted 22-12-2015)

\begin{abstract}
ABSTRAK
Kusumaningrum DA, Purwantara B, Yusuf TL, Situmorang P. 2015. Mikroenkapsulasi spermatozoa sapi: Kriopreservasi mikroenkapsulasi spermatozoa menggunakan gliserol. Indones J Anim Vet Sci. 20(4): 233-241. DOI: http://dx.doi.org/10.14334/jitv.v20i4.1240

Kriopreservasi spermatozoa merupakan proses preservasi spermatozoa yang dilakukan pada suhu yang sangat rendah. Krioprotektan intraselular gliserol merupakan krioprotektan yang paling sering dikombinasikan dengan pengencer Tris sitrat yang mengandung 20\% kuning telur (TSKT), sementara TSKT juga digunakan sebagai media enkapsulasi bersama dengan 1,5\% alginat. Pengaruh alginat dalam mikroenkapsulasi dan gliserol terhadap daya hidup spermatozoa ( motilitas $=\% \mathrm{M}$, spermatozoa hidup $=\% \mathrm{H}$ dan Tudung akrosom utuh $=\% \mathrm{TAU}$ ) diteliti dalam dua tahapan penelitian. Pada penelitian pertama, pengaruh alginat dan proses mikroenkapsulasi dipelajari dengan tiga perlakuan yaitu: 1) TSKT ditambah dengan semen; 2) TSKT-Alginat ditambah dengan semen dan 3) TSKT-Alginat ditambah semen dengan mikroenkapsulasi; yang diikuti dengan proses kriopreservasi spermatozoa secara konvensional menggunakan TSKT 7\% gliserol. Pada penelitian kedua pengaruh konsentrasi gliserol (5 dan 7\%) dan waktu ekuilibrasi diteliti menggunakan disain faktorial 2 x 2. Proses pembentukan mikroenkapsulasi berpengaruh nyata terhadap persentase motilitas spermatozoa (\%M) dan tudung akrosom utuh (\%TAU) pada post-thawing, yaitu 44,17 dan 50,83\% untuk \% dan 79,33 dan 83,59\% untuk \% TAU berturut turut untuk mikroenkapsulasi dan kontrol. Dijumpai adanya fakta bahwa alginat berperan sebagai krioprotektan ekstraseluler karena kemampuannya dalam mencegah penurunan daya hidup spermatozoa selama proses kriopreservasi. Rata-rata persentase penurunan dari \% $\mathrm{M}$ dan $\% \mathrm{TAU}$ pada TSKT-Alginat 15,97 dan 6,44\%, lebih rendah dibandingkan kontrol-TSKT yaitu 23,8 and 7,37\%. Dijumpai adanya kenyataan bahwa alginat berperan sebagai krioprotektan ekstraselular karena kemampuannya melindungi spermatozoa selama proses pembekuan, sehingga persentase penurunan dari \% dan \%TAU pada TSKT-alginat (15,97 dan 6,44\%) lebih rendah dibandingkan dengan kontrol-TSKT yaitu 23,80 dan $7,37 \%$. Tidak dijumpai adanya pengaruh yang nyata dari konsentrasi gliserol (5 dan $7 \%$ ). Disimpulkan, proses mikroenkapsulasi menurunkan daya hidup spermatozoa, alginat berperan sebagai krioprotektan ekstraselular sehingga kriopreservasi dari mikroenkapulasi spermatozoa dapat dilakukan menggunakan gliserol 5 atau $7 \%$.
\end{abstract}

Kata Kunci: Spermatozoa, Alginat, Mikroenkapsulasi, Gliserol, Waktu Ekuilibrasi

\section{ABSTRACT}

Kusumaningrum DA, Purwantara B, Yusuf TL, Situmorang P. 2015. Microencapsulation of bovine sperm: Cryopreservation microencapsulation of sperm using glycerol. Indones J Anim Vet Sci. 20(4): 233-241. DOI: http://dx.doi.org/10.14334/jitv.v20i4.1240

Cryopreservation of spermatozoa has been used to preserve spermatozoa in very low temperatures. Glycerol is intracelullar cryoprotectant usually used in Tris citrate containing 20\% egg yolk (TCEY), while TCEY-1.5\% alginate was used as encapsulation media. The effect of alginate in microencapsulation process and glycerol concentration on viability spermatozoa (motility (\%M), live sperm (\%L) and intact apical ridge (\%IAR) were studied in two steps. In the first step, the effect of alginate and microencapsulation process was studied. Three treatments of this step were: 1) TCEY add with semen (as control), 2) TCEY-Alginate add with semen, 3) TCEY-Alginate add with semen and microencapsulated, followed by conventional sperm cryopreservation using TCEY 7\% glicerol. The second steps were done to evaluate the effect of two glycerol concentrations (5 and $7 \%$ ) and two duration of equilibration time (3 and 4 hours). Result of these experiments showed, that microencapsulation was significantly alter the percentage of post-thawing motility (\%M) and intact apical ridge (\%IAR). The motility of microencapsulated sperm vs control was 44.7 and $50.83 \%$ respectively, whereas IAR $79.33 \%$ and $83.50 \%$ on microencapsulated sperm and control. There was evidence that alginate act as extracelullar cryoprotectant by protecting sperm during freezing. The mean of decreasing percentage of $\% \mathrm{M}$ and \%IAR in TCEY-Alginate were lower (15.97 and 6.44\%) than control (23.80 and 7.37\%). The effect of glycerol concentration and equilibration time on the viability of sperm was not significant different. There was no significant interaction of glicerol and equilibration time on the viability of spermatozoa. In conclution, microencapsulation processes altered the viability of sperm, alginate had an important roles as extracelullar cryoprotectant. Moreover the cryopreservation of microencapsulated sperm might be done using 5 or $7 \%$ glycerol in 3-4 hours duration of equilibration time.

Key Words: Sperm, Alginate, Microencapsulation, Glycerol, Equilibration Time 


\section{INTRODUCTION}

The cryopreservation of sperm is preservation process of sperm cell performed at very low temperature (commonly at $-196^{\circ} \mathrm{C}$ by using $\mathrm{N}_{2}$ liquid). Temperature decreasing process causes changing media environment (osmolatiry increase and ice crystal formation) which damaging the cell.

During cryopreservation process, sperm undergo stress due to temperature decrease. Temperature stress will be decrease the function and fertility of sperm. Some sperm cryopreservation problem were decreasing of viability of sperm more than $50 \%$, induction of acrosome reaction, decrease of motility and problem of fertility (Chavero et al. 2006; Wongtawan et al. 2006). Sperm damage occurred through two mechanisms: due to mechanic process through ice crystal formation and due to ostmotic effect and solute concentration known as solute effect (Wowk 2007). Addition of cryoprotectant agent was conducted to decrease the lethal effect of the ice crystal formation and solute effect.

According to ability to penetrete cell membrane, cryoprotectant was divided as intracellular and extracellular cryoprotectant. Intracellular cryoprotectant can penetrate membrane cell, such glycerol, methanol, dimethyl sulfoxide (DMSO), 1.2 propanediol, butanediol, acetamide, propylene glycol. Extracellular cryprotectant have high molecular weight, can't penetrate into the cell and works outside the cell. Lactose, raffinose, mannase, polyethylene glycol (PEG), polyvinylpyrrolidone (PVP), trehalose and proteins such as lipoprotein of egg yolk ware extracelullar cryoprotectant. (Wowk 2007; Lemma 2011).

Glycerol (C3H8O3), alcoholic sugar with BM 92.09 , high solubility in water, freezing point at $-38^{\circ} \mathrm{C}$, and low toxicity (Fuller 2004). Glycerol is the most popular cryoprotectant for crypreservation of bovine sperm. The aplication of glycerol concentration dependent on species, in livestock animal 2-10\% were applied. In bovine, $5-10 \%$ was applied but optimum concentration was 6-8\% (Miller \& Van Demark 1953). Glycerol applicating in one step was reported slightly toxic for sperm, then the glycerol was added in extender and given stepwise during the cooling process in a hour.

Action mechanism of intracellular cryoprotectant in maintaining cell during cryoproservation process was by replacing and filling the room left by water cell. By the low frozen point, glycerol was able to reduce cell damage caused by solution injury and ice crystallization (Fuller 2004; Andrabi 2007; Wowk 2007; Lemma 2011).

Intracellular cryoprotectant toxicity was highly depended on species response, concentration, temperature, and delivery technique (Wowk 2007). Glycerol were not toxic, but some research indicated toxicity glycerol in any species. The combination of intracelullar cryoprotectan glycerol with any extracelullar cryoprotectant can reduce the toxicity.

External cryoprotectant only worked on outside the cell with the same mechanism with the intracellular cryoprotectant. The extracellular cryoprotectant commonly is a carbohydrate or protein polimer. Alginate as encapsulation media component of sperm microencapsulation is expected may be act as extracellular cryoprotectant. Alginate is carbohydrate polimer with high molecule weight, not toxic, and can not penetrate spermatozoa cell membrane. There were no study of alginate action as extrecelullar cryoprotectant but carbohydrate polimer methyle cellulose was reported could be combined with glycerol to reduce glycerol negative effect against chicken's sperm fertility (Phillips et al. 1996). Alginate has also been applied in cryopreservation of prebiotic and fish. (Venugopal 2011; Pop et al. 2015).

This studys were conducted to determine the cryopropreservation technique of sperm microencapsulated using glycerol, to observe function of alginate "micro-encapsulation component " as extracellular cryoprotectant agent, whether process of microcapsulation affects sperm viability and to determine glycerol concentration at the cryopreservation of sperm microencapsulation. The final goal of this study was to increase artificial insemination efficiency.

\section{MATERIAL AND METHODS}

Sperm cryopreservation was performed in two experiment. First experiment was to determine alginate and microencapsulation effect against sperm viability and second experiment was to determine glycerol concentration and equilibration time against sperm viability.

\section{Time and location}

This study was conducted on June 2013-April 2014 at Laboratory of Reproduction Physiology, Indonesian Research Institute for Animal Production.

\section{Semen sample and semen quality evaluation}

Three FH bulls (3-4 years old) were used and semen was collected twice a week using artificial vagina. Fresh semen quality observation was performed microscopically and macroscopically including color, consistentce, mass movement, live sperm percentage $(\% \mathrm{~L})$, and intact acrosome ridge (\%IAR). 
Alive spermatozoa $(\% \mathrm{~L})$ were observed using smear preparate by eosin-negrosin dye. Observation was performed using light microscope with 100 x 10 magnifications. Dead spermatozoa would absorb the dye represent red color and the live were trasparant. Two hundred live and dead sperm were counted in 1 object glass and the live sperm were counted by following formulation:

$$
\text { Live sperm }(\% \mathrm{~L})=\frac{\text { Number live sperm }}{\text { Total sperm observed }} \times 100 \%
$$

Observation of \%IAR was performed by observation sperm in $\mathrm{NaCl}$ formaline solution $(0.01 \%$ w/v). One hundred sperm were observed under contrast phase microscope with $100 \times 10$ magnification using emersy oil. Percentage of IAR was calculated using the following formula:

\section{$\%$ IAR $=\underline{\text { The number black hood sperm } \times 100 \%}$ Total sperm observed}

Semen from 2 ejaculates (minimum mass movement was,$++ \% \mathrm{~L}$ was $>80 \%$, and concentration was more than $800 \times 106 / \mathrm{ml}$ ) were mixed proportionally to be used as sample. The pool semen was evaluated to obtain fresh semen quality data and used as repetition.

\section{Microcapsulation Sperm Preparation}

Twenty five $\mathrm{ml}$ encapsulation media (Table 1) was mixed with semen sample to get total concentration sperm 100 million/ml. Microgel formation was performed using microencapsulator Buchi B 390 (750 $\mathrm{Hz}, 550$ volt). Droplets of media were collected into baker tube consisting $1.5 \% \mathrm{CaCl}_{2}$ and stirred using magnetic stirrer.

Table 1. Composition of Tris Citrate yolk-Alginat (TCEY-A) encapsulation media

\begin{tabular}{lc}
\hline \hline Chemical materials & Composition \\
\hline Tris Hidroxymethil Aminomethan (g) & 3.027 \\
Citric Acid (g) & 1.675 \\
Fructose (g) & 1.25 \\
Streptomycin (mg) & 100 \\
Penicylin (IU) & 100000 \\
Glutation (mM) & 1 \\
Aquabides (ml) & 80 \\
Yolk (ml) & 20 \\
Alginate (g) & 1.5
\end{tabular}

Microgel formed was washed using physiological $\mathrm{NaCl}(3 \mathrm{x})$ and weighed as $4 \mathrm{~g}$ as sample. Microcapsule membrane formation was performed using $1 \%$ chitosan
( $\mathrm{pH}$ 5.5) for 15 minutes. The microcapsule was rinsed using physiological $\mathrm{NaCl}(3 \mathrm{x})$ and liquid core performing was performed using $2 \% \mathrm{Na}$ Citrate for 10 minutes. Evaluation of sperm viliability was conducted as soon as after microencapsulation process finished. The evaluation of sperm viability do using freezing media A (Table 3). It was used as initial data of sperm viability. Spermatozoa viliability variables observed were motility percentage $(\% \mathrm{M}), \% \mathrm{~L}$, and $\%$ IAR.

Percentage of motility $(\% \mathrm{M})$ in the microencapsulation was observed by damaging microcapsule membrane using coverslip. Motility was observed under light microscope (100x10 magnification). The $\% \mathrm{~L}$ and $\% \mathrm{IAR}$ were observed after microencapsule membrane were damaged using repetitive pipetting method (Kusumaningrum 2016).

\section{Research 1}

Research 1 was performed to determine the effect of alginate and microencapsulation process to viliability of sperm at each stage of freezing. Completely randomized design was used with 3 treatments and 6 repetitions. The treatments were T-I (semen sample in Tris citrate Egg Yolk_TCEY as control), T-II (semen sample in TCEY-A) and T-III (semen sample in TCEY-A followed by microcapsulation forming).

Semen sample was diluted using 3 diluent treatments to reach the final sperm cocentration $100 \mathrm{x}$ $10^{6} / \mathrm{ml}$. Evaluation of sperm viliability both of T-I, T-II, and T-III (\%M, \%L and \%IAR) was performed after microencapsulation process (T-III) finished. Those data were used as initialy sperm viability data.

Feezing process both of T-I, T-II, and T-III was carried out by freezing standard of bovine's sperm using Tris citric extender consisting of $20 \%$ yolk and $7 \%$ glycerol (Table 3) with equilibration time was 3 hours. Addition of freezing media (media A and B) was performed gradually started from room temperatur decrease until $5^{\circ} \mathrm{C}$ by using cooling machine.

Four ml sample semen (TI and TII) and four grams of microencapsule were add with $4 \mathrm{ml}$ media $\mathrm{A}$ and $\mathrm{B}$ (Table 2) as following:

1. Addition of media $\mathrm{A}$ was performed after microcapsulation finished $(2 \mathrm{ml})$

2. Additional of media $\mathrm{B}$ was performed at 15 and $10^{\circ} \mathrm{C}(2 \mathrm{ml})$

The final concentration of sperm after that process was $50 \times 10^{6} / \mathrm{ml}$ with glycerol concentration $7 \%$. After temperature was at $5^{\circ} \mathrm{C}$, evaluation of sperm viability $(\% \mathrm{M}, \% \mathrm{~L}$ and $\% \mathrm{IARAU})$ was carried out. Equlibration was carried out at $5^{\circ} \mathrm{C}$ for 3 hours. In first 1 hour equilibration, semen was packed into medium straw (0.5 ml, 25x10\%/straw). Equlibration was continued in the straw until 3 hours equilibration. 
Straw were freezed on $8 \mathrm{~cm}$ upper $\mathrm{N}_{2}$ liquid for 10 minuts, then plung in $\mathrm{N}_{2}$ liquid. Frozen sperm evaluation was carried out after 1 week storage. The straw were thawed using warm water $\left(37^{\circ} \mathrm{C}\right)$ for 30 seconds, and sperm vialbility $(\% \mathrm{M}, \% \mathrm{~L}$, and \% IAR) was evaluated. The datas were record as post-thawing data. Viliability data (initialy, $5^{\circ} \mathrm{C}$, and post-thawing data) was analyzed by ANOVA and mean difference was tested using Duncan (SAS 9.1).

\section{Research 2}

This study was conducted by $2 \times 2$ factorial Completely Ramdomized Design with 6 repetitions. As first factor was glycerol concentration by 5 and $7 \%$ and

Table 2. Composistion of TCEY and TCEY-Alginate extender

\begin{tabular}{lcc}
\hline \hline Chemical composition & TCEY & TCEY-Alginate \\
\hline Tris Hydroxy Amino-methan (g) & 3.027 & 3.027 \\
Citric acid (g) & 1.675 & 1.675 \\
Fructose (g) & 1.25 & 1.25 \\
Streptomycin (mg) & 100 & 100 \\
Penicylin (IU) & 100000 & 100000 \\
Glutation (mM) & 1 & 1 \\
Aquabides (ml) & 80 & 80 \\
Yolk (ml) & 20 & 20 \\
Alginate (g) & - & 1.5 \\
\hline
\end{tabular}

the second factor was equilibration time by 3 and 4 hours.

$2 \mathrm{ml}$ of media A (Table 4) were added in 4 gram microcapsule, in room temperature. Temperature of suspension of semen was decreased using cooling mechine, temperature will decrease gradually until $5^{\circ} \mathrm{C}$ ( \pm 60 minutes). Two $\mathrm{ml}$ freezing media B (Table 4 ) was added stepwise at $15^{\circ} \mathrm{C}$ and $10^{\circ} \mathrm{C}$ to obtain sperm concentration by $50 \mathrm{x} 10^{6} / \mathrm{ml}$ with glycerol concentration by 5 and $7 \%$.

Equilibration was carried out in the cool top $\left(5^{\circ} \mathrm{C}\right)$ for 3 and 4 hours. Packaging of sperm microencapsulated were performed using medium straw $\left(0.5 \mathrm{ml}, 25 \times 10^{6} / \mathrm{straw}\right)$ at 1 hour after equilibration. Straws were seal using poliviline powder and equilibration was continued until 3 and 4 hours.

Table 3. Composittion of sperm freezing media (media A and B)

\begin{tabular}{lcc}
\hline \hline Chemical composition & Media A & Media B \\
\hline Tris Hydroxy Amino-methan (g) & 3.027 & 3.027 \\
Citric acid (g) & 1.675 & 1.675 \\
Fructose (g) & 1.25 & 1.25 \\
Streptomycin (mg) & 100 & 100 \\
Penicylin (IU) & 100000 & 100000 \\
Glutation (mM) & 1.0 & 1.0 \\
Aquabides (ml) & 80 & 80 \\
Yolk (ml) & 20 & 20 \\
Glycerol (ml) & 0 & 28 \\
\hline
\end{tabular}


The freezing of straw were perfomed using the same methode before. The evaluation of post thawing were done 1 week after storage in $\mathrm{N}_{2}$ liquid using same methode.

Sperm viability was analyzed using ANOVA. Difference between treatment was tested using Duncan and LSD if there was significant interaction between glycerol concentration and equilibration time (SAS 9.1).

\section{RESULT AND DISCUSSION}

\section{Quality of fresh semen}

Fresh semen used in this study was feasible to be used in sperma cryopreservation process. The semen has sufficient volume and concentration, average volume $5 \mathrm{ml}$, concentration $1160 \times 10^{9}$, average percentage of live sperm $82.6 \%$ and $87.7 \%$ IAR.

\section{Research 1}

Alginate and sperm microencapsulation process was affacting sperm vialbility at initial of cryopreservation process.

Sperm motility $(\% \mathrm{M})$ in media consisting alginate (T-1II) was lower $(\mathrm{P}<0.05)$ than control $(\mathrm{T}-\mathrm{I})$, meanwhile microencapsulation process caused $\% \mathrm{M}$ on encapsulated T-III $(55.00 \%)$ was lower $(\mathrm{P}<0.05)$ than unencapsulated. (66.71 and $60.00 \%$ for T-I and T-II, respectively).

The percentage of live sperm (\%L) T-III (82\%) was also lower $(\mathrm{P}<0.05)$ than non-encapsulated $(90.14$ and and 86.57 for T-I and T-II, respectively).

The percentage of IAR (\%IAR) was not significantly different caused by alginate and microencapsulation process (Table 5).

\section{Viability of sperm at initialy of cryopreservation}

Sperma vialbility (\%M, \%H dan $\% \mathrm{IAR})$ at the beginning of cryopreservation varied depending on process and media where spermatozoa stayed for a hour at the room temperature. Sperm viability inT-PI and TII was in line with previous study conducted by Kusumaningrum et al. (2105), where \% $\mathrm{M}$ in media TCEY-Alginate (T-II) lower $(\mathrm{P}<0.05)$ than TSKT $(\mathrm{T}-\mathrm{I})$, but $\% \mathrm{~L}$ and $\% \mathrm{IAR}$ were not significant different.

TCEY-Alginate $(\mathrm{T}-\mathrm{II})$ lower $(\mathrm{P}<0.05)$ than TSKT (T-I), but $\% \mathrm{~L}$ and $\%$ IAR were not significant different. Microencapulation process (T-III) significant lower $(\mathrm{P}<0.05)$ than non-microencapsulation $(\mathrm{T}-\mathrm{I}$ and $\mathrm{T}-\mathrm{II})$ at initial quality $(\% \mathrm{M}$ and $\% \mathrm{H})$.

Microencapsulation process consisting of 3 stage and every stage is physically and chemicaly give stress to the sperm. At the first stage, formation of microgel: interaction sperm with media TCEY consisting $1.5 \%$ alginate which high osmilarity and viscosity decrese the sperm motility (Kusumaningrum et al. 2015). A contact between microencapsulation media with gel former media $\left(1.5 \% \quad \mathrm{CaCl}_{2}\right)$ causing the sperm in immobilization phase. That contact also change sperm membrane condition, where $\mathrm{Ca}$ would stimulate change of distribution of lipid and composition pospolipid membrane as occurred on capacitation and acrosome reaction (Landim-Alvarenga et al. 2004)

In the second stage (alginate-chitosan membrane forming), sperm linked with chitosan solution with $\mathrm{pH}$ 5.5 and followed by washing process. Low $\mathrm{pH}$ might cause lost of spermatozoa membrane integrity (Bohloodi et al. 2012).

In the third stage, reaction of microcapsule-sodium citric solution causing sperm condition change from immotile into motile sperm inside the encapsulation

Table 4. Composition of freezing media A and B with different glycerol concentration

\begin{tabular}{lccc}
\hline \hline & & & \multicolumn{2}{c}{ Media B } \\
\cline { 3 - 4 } Chemical composition & Media A & Glycerol 5\% & Glycerol 7\% \\
\hline Tris Hydroxy Amino-methan (g) & 3.027 & 3.027 & 1.027 \\
Citric acid (g) & 1.675 & 1.675 & 1.25 \\
Fructose (g) & 1.25 & 1.25 & 100 \\
Streptomycine (mg) & 100 & 100 & 100000 \\
Penicylin (IU) & 100000 & 100000 & 1 \\
Glutation (mM) & 1 & 1 & 80 \\
Aquabides (ml) & 80 & 80 & 20 \\
Yolk (ml) & 20 & 20 & 28 \\
Glicerol (ml) & 0 & 20 & 2 \\
\hline
\end{tabular}


Table 5. Effect of alginate and sperm microencapsulation process to sperm vialibity

\begin{tabular}{|c|c|c|c|c|}
\hline \multirow{2}{*}{ Cryopreservation stage } & \multirow{2}{*}{ Parameter } & \multicolumn{3}{|c|}{ Treatment } \\
\hline & & T-I & T-II & T-III \\
\hline \multirow{3}{*}{ Initialy } & $\% \mathrm{M}$ & $66.71 \pm 6.07^{\mathrm{a}}$ & $60.00 \pm 6.45^{\mathrm{b}}$ & $55 ., 71 \pm 3.45^{\mathrm{c}}$ \\
\hline & $\% \mathrm{~L}$ & $90.14 \pm 5.70^{\mathrm{a}}$ & $86.57 \pm 6.55^{\mathrm{a}}$ & $82.00 \pm 6.30^{\mathrm{b}}$ \\
\hline & $\%$ IAR & $90.14 \pm 6.62^{\mathrm{a}}$ & $91.20 \pm 6.00^{\mathrm{a}}$ & $90.71 \pm 5.50^{\mathrm{a}}$ \\
\hline \multirow{3}{*}{$5^{\circ} \mathrm{C}$} & $\% \mathrm{M}$ & $61.43 \pm 2.40^{\mathrm{a}}$ & $60.71 \pm 1.89^{\mathrm{a}}$ & $55.00 \pm 5.00^{\mathrm{b}}$ \\
\hline & $\% \mathrm{~L}$ & $89.14 \pm 9.70^{\mathrm{a}}$ & $86.86 \pm 8.15^{\mathrm{a}}$ & $82.86 \pm 4.42^{\mathrm{a}}$ \\
\hline & $\%$ IAR & $90.86 \pm 3.02^{\mathrm{a}}$ & $90.86 \pm 2.61^{\mathrm{a}}$ & $85.71 \pm 5.72^{\mathrm{b}}$ \\
\hline \multirow{3}{*}{ Post thawing } & $\% \mathrm{M}$ & $50.83 \pm 1.95^{\mathrm{a}}$ & $50.42 \pm 1.44^{\mathrm{a}}$ & $44.17 \pm 6.22^{\mathrm{b}}$ \\
\hline & $\% \mathrm{~L}$ & $83.58 \pm 1.95^{\mathrm{a}}$ & $79.33 \pm 5.87^{\mathrm{a}}$ & $80.75 \pm 5.36^{\mathrm{a}}$ \\
\hline & $\%$ IAR & $83.50 \pm 8.02^{\mathrm{a}}$ & $85.33 \pm 8.93^{\mathrm{a}}$ & $79.33 \pm 7.91^{\mathrm{b}}$ \\
\hline
\end{tabular}

${ }^{\mathrm{a}, \mathrm{b}}$ Different letter in the same line shows significant difference $(\mathrm{P}<0.05)$

Initialy $=$ sperm viability observed simultanouslly before cryopreservation process

$5^{\circ} \mathrm{C}=$ sperm viability at $5^{\circ} \mathrm{C}$

Post thawing $=$ sperm viability observed after thawing using water $37^{\circ} \mathrm{C}$ for 30 second

media. Rinsing process in every stage was other than to remove the substance excess, preventing occurrence of unexpected reactions, but also causing osmotic change of sperm caused by the dilution. It was reported that dilution caused ion concentration change other than causing dilution effect deceasing sperm viability (Hayden et al. 2015).

The microencapsulation process caused sperm quality decrease, especially the significant effect to $\% \mathrm{M}$ and \%L compared to \%IAR. In spite of the \%IAR in the initial cryopreservation was not significant which was affected by microencapsulation process, but this process caused acrosome ridge more sensitive to temperature change during cooling and freezing, so that decrease percentage of IAR decrease percentage on encapsulated sperm higher than non-encapsulated (Figure 1).

\section{Viability of sperm at $5^{\circ} \mathrm{C}$}

The decrease of temperature was significantly affect $\% \mathrm{M}$ and $\% \mathrm{IAR}$, where the $\% \mathrm{M}$ and \%IAR in the sperm microencapsulation $(\% \mathrm{M}=55 \%, \%$ IAR $=85.7 \%)$ was lower than non-encapsulated spermatozoa (average $\% \mathrm{M}$ and \%TAU of T-II and T-III was $61.07 \%$ and \%IAR was $90.86 \%$ respectively). Spermatozoa viability at the initialy of microencapsulation process was be a main factor in this stage, meanwhile other factors associated with cooling process until reaching $5^{\circ} \mathrm{C}$. Cold shock was not occurred in this study. Microencapsulation formation process as in T-III was indicated significant \%IAR decrase compared to the T-I and T-II. The main factor causing spermatozoa quality decrease during temperature decrease to $5^{\circ} \mathrm{C}$ was cold shock (Andrabi 2007) marked by cell metabolism decrease, membrane permeability increase, intracellular component losses, permanently motility decrease and increase of the number of dead cell (Lemma 2011).

Temperature decrease was significantly affect $\% \mathrm{M}$ and \%IAR on encapsulated spermatozoa (T-III), where $\% \mathrm{M}$ and \%IAR significantly lower $(\mathrm{P}<0.05)$ compared non-encapsulated. Decrease of $\% \mathrm{M}$ and \%IAR indicated an inhibition of microcapsule membrane and encapsulation media (high viscocity and osmolarity) causing glycerol effect to spermatozoa in microcapsule membrane became slow. Not like glycerol affecting sperm in the commonly freezing process, where glycerol was able to penetrate cell membrane in 2-5 minuts. It seemed that glycerol needed time to penetrate microcapsule membrane and encapsulation media which had high osmolarity and viscosity. To prevent decrease of \%IAR during cooling process, modification of additional time before critical period of cold shock between $15-5^{\circ} \mathrm{C}$ was needed (Watson 2000).

\section{Viability of post-thawing sperm}

Freezing and thawing processes was significantly affected motility and integrity of acrosome membrane of sperm, where $\% \mathrm{M}$ and \% IAER of encapsulated spermatozoa was lower $(\mathrm{P}<0.05)$ compared to nonencapsulated, meanwhile $\% \mathrm{~L}$ was not significantly affected by the freezing and thawing processes.

Quality of post-thawing of encapsulated spermatozoa, other than affected by freezing and thawing process, was also affected by preliminary quality and process of glycerol addition before reaching $5^{\circ} \mathrm{C}$. Equilibration for 3 hours was success to improved quality of sperm microencapsulate (T-III), because 
Table 6. Effect of glycerol and equilibrium time on post thawed sperm vialbility

\begin{tabular}{|c|c|c|c|c|}
\hline \multirow{2}{*}{ Parameter } & \multirow{2}{*}{ Equilibration (hour) } & \multicolumn{2}{|c|}{ Glycerol (\%) } & \multirow{2}{*}{ Average } \\
\hline & & 5 & 7 & \\
\hline \multirow{3}{*}{$\% \mathrm{M}$} & 3 & $42.14 \pm 7.56$ & $43.86 \pm 6.36$ & $42.50 \pm 6.72^{\mathrm{a}}$ \\
\hline & 4 & $43.57 \pm 4.76$ & $44.29 \pm 4.50$ & $43.93 \pm 4.66^{\mathrm{a}}$ \\
\hline & Average & $42.87 \pm 6.16^{\mathrm{a}}$ & $43.56 \pm 5.35^{\mathrm{a}}$ & \\
\hline \multirow{3}{*}{$\% \mathrm{~L}$} & 3 & $77.29 \pm 6.25$ & $80.29 \pm 5.47$ & $78.78 \pm 5.05^{\mathrm{a}}$ \\
\hline & 4 & $77.57 \pm 4.58$ & $79.86 \pm 5.43$ & $78.72 \pm 4.97^{\mathrm{a}}$ \\
\hline & Average & $77.43 \pm 6.72^{\mathrm{a}}$ & $80.71 \pm 5.26^{\mathrm{a}}$ & \\
\hline \multirow{3}{*}{$\%$ IAR } & 3 & $76.86 \pm 8.36$ & $78.14 \pm 6.26$ & $77.50 \pm 7.75^{\mathrm{a}}$ \\
\hline & 4 & $78.29 \pm 7.70$ & $78.86 \pm 8.09$ & $78.57 \pm 6.69^{\mathrm{a}}$ \\
\hline & Average & $77.57 \pm 7.12^{\mathrm{a}}$ & $78.50 \pm 7.59^{\mathrm{a}}$ & \\
\hline
\end{tabular}

${ }^{\mathrm{ab}}$ Different superscrip in the same column and lines shows significant difference $(\mathrm{P}<0.05)$

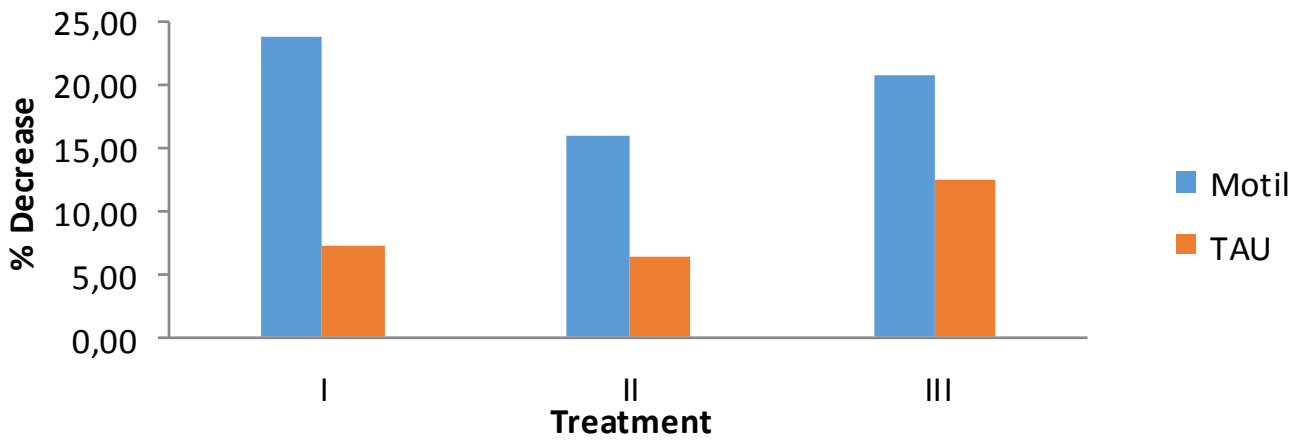

Figure 1. Percentage of decrease of $\% \mathrm{M}$ and \%IAR due to alginate (II) and microcapsulation process (III) compared with control (I)

glycerol had proven protective effect to sperm inside the microencapsulate membrane. Glycerol was able to protect sperm cell in the microcapsule, so that during freezing and thawing process, \%IAR of T-III only decreased by $6.38 \%$, meanwhile decrease of \%IAR T-II was $5.53 \%$ and the control (T-I) decreased by $7.36 \%$ (Table 6).

The percentage of decreasing $\% \mathrm{M}$ and \%IAR counted to determine contribution of alginate and process of microencapsulation to $\% \mathrm{M}$ and $\% \mathrm{IAR}$ of the post-thawing. The decreasing of percentage of $\% \mathrm{M}$ and $\%$ IAR at the initial of freezing until post-thawing were presented in the Figure 1.

Percentage of decrease of post-thawing quality in the T-II $(15.97 \%$ for $\% \mathrm{M}$ and $6.44 \%$ for $\%$ IAR) was lower than T-I (23.8\% for \%M and $7.73 \%$ for \%IAR). It indicated there was alginate role considering that T-II consisted of $0.75 \%$ alginate in to total media added.

Decrease of sperm quality in T-III higher than T-II (20.71\% for $\% \mathrm{M}$ and 12.55 for $\%$ IAR) showed that contribution of microcapsulation process against $\% \mathrm{M}$ and \%IAR post-thawing of microencapsulation sperm.
Lower percentage decrease of $\% \mathrm{M}$ dan $\% \mathrm{IAR}$ in T-III compared to T-I also showed alginate effect.

Alginate, carbohydrate polimer with high molecule weight, migh play role as extracellular cryoprotectant due to its ability to protect sperm then decrease of $\% \mathrm{M}$ and \%IAR from T-II lower than control (T-I). Alginate protection mechanism was extracellular ptotection mechanism, because alginate might not able to penetrate cell membrane. Action mechanism of alginate in this study has not been known.

Alginate use as extracellular cryoprotectant in sperm cryopreservation has not been reported before. It was reported that carboxyl cellulose (similar with alginate) might be used as extracellular cryoprotectant at chicken's semen cryopreservation (Phillips et al. 1996). Alginate was also used in cryopreservation of fish to prevent protein denaturation (Venugopal 2011) and cryopreservation of probiotik (Pop et al. 2015). Futher study of role and concentration of alginate as extracellular cryprotectant in sperm cryopreservation process was needed. 


\section{Research 2}

There was no significant interaction between glycerol concentration with equilibrium time. Decrease of glycerol concentration from $7 \%$ into $5 \%$ did not significantly affect viliability of sperm microencapsulation both in $\% \mathrm{M}, \% \mathrm{~L}$, and $\% \mathrm{IAR}$ (Table 6).

The process of cryopreservation of sperm microencapsulation were done using conventional process of cryopreservation sperm. Bovine sperm cryopreservation was commonly performed using combined TCEY (20\% yolk) extender and glycerol at $7 \%$ concentration. Glycerol added during cooling process (Muino et al. 2007) and followed by equlibration at $4-5^{\circ} \mathrm{C}$ (Leita et al. 2010) for 2-18 hours to obtain optimal fertility (Muino et al. 2007).

Equilibration period length was feared to be a cause of fertility decrease caused by sperm aging process, so that shortening the equilibration period was an option. Effect of equilibration time to sperm motility, membrane integrity, and mitocondria function were still being debated. However, previous study showed that equilibration time by 4-6 hours produced the best motility, meanwhile study using CASA against progresive of motility and integrity of plasm and acrosome mebrane showed 4 hours equilibrium was the best time for bovine spermatozoa cryopreservation process (Leita at al. 2010).

The duration of equilibration at cryopreservation of microencapsulated sperm, showed that 4 hours equilibration had no significant different (on $\% \mathrm{M}, \% \mathrm{~L}$, and \%IAR) compared to the 3 hours equilibrium. There is no previous study about optimal equilibrium time in cryopreservation of microencapsulation of bovine sperm.

The effect of glycerol concentration (7 vs 5\%) at freezing of microencapsulation sperm freezing were not significantly, so that the $5 \%$ glycerol might be used to reduce negative effect of glycerol. Glycerol concentration $7 \% 1$ was optimal concentration to be used in bovine spermatozoa cryopreservation (Miller \& Van Demark 1953). Glycerol concentration $7 \%$ is optimal concentration to be used in bovine sperm cryopreservation (Miller \& Van Demark 1953). In cryopreservation of sperm microencapsulation, the concentration of glycerol might be decreased into $5 \%$. The decrease concebtration from $7 \%$ into $5 \%$ did not cause harm effect to $\% \mathrm{M}, \% \mathrm{~L}$ and $\% \mathrm{IAR}$. This was caused by alginate role which was a part of encapsulation media. Alginate may act as extracellular cryoprotectants such as the role of the cellulose in the cryopreservation of poultry semen (Phillips et al. 1996). Further study on effect of alginate concentration decrease from $7 \%$ into $5 \%$ by considering alginate as extracellular cryoprotectant agent needed to be developed.

\section{CONCLUSION}

Cryopreservation for microencapsulated of bovine sperm could be carried out using standard protocol cryopreservation bovine sperm. Glycerol can be aplicated in concentration 5 or $7 \%$ with time of equilibration 3-4 hour.

Microencapsulation processes altered the viability of sperm. Alginate might play a role as extracellular cryoprotectant due to its ability to prevent $\% \mathrm{M}$ and $\%$ IAR decreasing along the freezing of microencapsulation sperm, due to alginate can be reduce glycerol concentration at $5 \%$. It was suggested to study alginate utilization as extracellular cryoprotectant.

\section{REFERENCES}

Andrabi SMH. 2007. Fundamental principles of cryopreservation of Bos taurus and Bos indicus bull spermatozoa. Int J Agric Biol. 9:367-369.

Bohloodi S, Codden F, Jang JP, Razzaghzadeh S, Bozoglu S. 2012. The effect of different extenders on post-thaw sperm viability, motility and membrane integrity in cryopreserved semen of Zandi Ram. J Basic Appl Sci Res. 2:1120-1123.

Chavero A, Machado L, Frijters A, Engel B, Woelders H. 2006. Improvement of parameters of freezing medium and freezing protocol for bull sperm using two osmotic supports. Theriogenology. 65:1875-1890.

Fuller BJ. 2004. Cryoprotectants: the essential antifreezes to protect live in the frozen state. CryoLetters. 25:375-388.

Hayden SS, Blanchard TL, Brisco SP, Verner DD, Henrichs K, Love CC. 2015. The "dilution effect" in stallion sperm. Theriogenology. 83:772-777. doi: 10.1016/j.theriogenology.2014.11.012.

Kusumaningrum DA, Purwantara B, Yusuf TL, Situmorang P. 2015. Mikroenkapsulasi Spermatozoa Sapi: Daya Hidup Spermatozoa pada Media Alginat-Kuning Telur. JITV. 20:1-9. doi: 10.14334/jitv.v20i1.1110

Kusumaningrum DA. 2016. Mikroenkapsulasi spermatozoa untuk meningkatkan efisiensi inseminasi buatan pada sapi perah (Dissertation). [Bogor: (Indones)]: Bogor Agriculture University.

Landim-Alvarenga FC, Graham JK, Alvarenga MA, Squires EL. 2004. Calcium influx into equine and bovine spermatozoa during in vitro capacitation. Anim Reprod. 1:96-105

Leita TG, Filho VR, Arruda RP, Andrade AFC, Emerick LL, Zaffalon FG, Martins JAM, Anrade VJ. 2010. Effec of extender and equilibration time on post-thaw motility 
and membrane integrity of cryopreserved gyr bull semen evaluated by CASA and flow cytometry. Anim Reprod Sci. 120:31-38. doi: 10.1016/j.anireprosci.2010. 04.005

Lemma A. 2011. Effect of cryopreservation on sperm quality and fertility. In: Artificial insemination in farm animal Manafi M, editor. In: Tech Open Science. doi: $10.5772 / 16563$.

Miller WJ, Van Demark NL. 1953. Factor afacting survival of bull spermatozoa at sub zero temperature. J Dairy Sci. 36:577.

Muino R, Fernandez M, Pena AI. 2007. Post-thaw survival and longevity of bull spermatozoa frozen with an egg yolk or two egg yolk-free extender after an equilibaration period $18 \mathrm{~h}$. Reprod Domes Anim. 42:305-311

Phillips JJ, Bramwell RK, Graham JK. 1996. Cryopreservation of rooster sperm using methyl celullose. Poult Sci. 75:915-923.
Pop LO, Diaconease Z, Thorsteen B, Ciuzan O, Pamfil D, Vodnar DC, Socacia C. 2015. Effect glycerol in the encapsulation and freeze drying of microspare containing probiotic. Bulletin Univ Agric Vet Med Food Sci Tech Clij-Napoca. 17.

Venugopal V. 2011. Marine Polysaccarida Food Aplication. In: Seaweed, Microalgae and There Polysaccaride. FRC Press. p. 250

Watson PF. 2000. The causes of reduce fertility with cryopreserved semen. Anim Reprod Sci. 60:481-492.

Wongtawan T, Seravia F, Wallgren M, Cabalerro I, Rodrigues-Mertinez. 2006. Fertility after deep uterine artificial insemination of concentrated low-volume boar semen doses. Theriogenology. 65:773-787.

Wowk B. 2007. How cryoprotectant work. Cryonic 3th ed. 28:3-7. 